\title{
LENGTH-WEIGHT AND LENGTH-LENGTH RELATIONS FOR 14 FISH SPECIES FROM THE CENTRAL MEXICAN PACIFIC COAST
}

\author{
Edgar R. SANDOVAL-HUERTA ${ }^{1 *}$, Xavier MADRIGAL-GURIDI², Omar DOMÍN- \\ GUEZ-DOMÍNGUEZ², Gorgonio RUIZ-CAMPOS ${ }^{3}$, and Adrián F. GONZÁLEZ-ACOSTA ${ }^{4}$ \\ ${ }^{1}$ Instituto Nacional de Pesca-SAGARPA, Centro Regional de Investigación Pesquera, Pátzcuaro, Michoacán, México \\ ${ }^{2}$ Laboratorio de Biología Acuática, Facultad de Biología, Universidad Michoacana de San Nicolás de Hidalgo, \\ Morelia, Michoacán, México \\ ${ }^{3}$ Laboratorio de Vertebrados, Universidad Autónoma de Baja California-Facultad de Ciencias, Ensenada, Baja Cali- \\ fornia, México \\ ${ }^{4}$ Centro Interdisciplinario de Ciencias del Mar, Instituto Politécnico Nacional, La Paz, Baja California Sur, México
}

Sandoval-Huerta E.R., Madrigal-Guridi X., Domínguez-Domínguez O., Ruiz-Campos G., González-Acosta A.F. 2015. Length-weight and length-length relations for 14 fish species from the central Mexican Pacific coast. Acta Ichthyol. Piscat. 45 (2): 199-201.

\begin{abstract}
Length-weight (LWR) and standard length-total length $(L-L)$ relations are presented for 14 fish species caught in four estuaries from the south-eastern coast of Michoacán, México (Central Pacific): Lile nigrofasciata Castro-Aguirre, Ruiz-Campos et Balart, 2002; Pliosteostoma lutipinnis (Jordan et Gilbert, 1882); Agonostomus monticola (Bancroft, 1834); Mugil curema Valenciennes, 1836; Poecilia butleri Jordan, 1889; Centropomus nigrescens Günther, 1864; Lutjanus novemfasciatus Gill, 1862; Eucinostomus currani Zahuranec, 1980; Dormitator latifrons (Richardson, 1844); Eleotris picta Kner, 1863; Gobiomorus maculatus (Günther, 1859); Awaous banana (Valenciennes, 1837); Gobionellus microdon (Gilbert, 1892); Trinectes fonsecensis (Günther, 1862). Values of $b$ ranged from 2.912 to 3.432 . The results revealed that length-weight relations for all species were highly correlated; likewise, length-length relations for all fishes also showed high correlation. This study presents for the first time, length-weight parameters for two species and length-length relations for six species.
\end{abstract}

Keywords: Actinopterygii, ichthyofauna, estuaries, Michoacán, LWR, regression models, Mexico

Length-weight relations (LWR) studies are used to predict the mean weight of fish when it is not possible to estimate it in field. They are also used to calculate the standing stock biomass, to analyse the ontogenetic changes, and to study other aspects of fish population dynamics like growth rates and age structure (Quist et al. 2012). This type of information is not available for fish species inhabiting the coastal zone of the state of Michoacán, Mexico. Thus, the goal of this study was to report data of the length-weight (LWR) and standard length-total length $(L-L)$ relations, for 14 fish species caught in estuaries from Michoacán (central Mexican Pacific).

Fish specimens were collected in four estuaries from the south-eastern coast of Michoacán: Barra de Nexpa $\left(18^{\circ} 05^{\prime} 07^{\prime \prime} \mathrm{N}, 102^{\circ} 47^{\prime} 18^{\prime \prime} \mathrm{W}\right)$, Teolán $\left(18^{\circ} 4^{\prime} 19^{\prime \prime} \mathrm{N}, 102^{\circ} 43^{\prime} 51^{\prime \prime} \mathrm{W}\right)$, Mexcalhuacán $\left(18^{\circ} 3^{\prime} 16^{\prime \prime} \mathrm{N}\right.$, $\left.102^{\circ} 39^{\prime} 28^{\prime \prime} \mathrm{W}\right)$, and Barra de Pichi $\left(17^{\circ} 58^{\prime} 28^{\prime \prime} \mathrm{N}\right.$, $\left.102^{\circ} 19^{\prime} 33^{\prime \prime} \mathrm{W}\right)$. The fishes were sampled bimonthly, from February 2010 through February 2011, using beach seines, cast nets, and trammel nets. Fish specimens, were deposited in the Aquatic Biology Laboratory of the Universidad Michoacana de San Nicolás de Hidalgo (UMSNH) to be identified using specialized keys. Standard (SL) and total (TL) lengths were measured to the nearest $1 \mathrm{~mm}$ using a digital calliper and weights were determined to the nearest $0.01 \mathrm{~g}$ with an electronic balance.

LWR was calculated from linear regression:

$$
\log W=\log a+b \log \mathrm{SL}
$$

where $W$ is the wet weight $[\mathrm{g}], \mathrm{SL}$ is the standard length of fish [cm], $a$ is a constant empirically determined (intercept), and $b$ allometry coefficient (slope) (Froese 2006).

\footnotetext{
" Correspondence: Edgar R. Sandoval Huerta M.Sc., Instituto Nacional de Pesca-SAGARPA, Centro Regional de Investigación Pesquera, Pátzcuaro, Calzada Ibarra 28, Colonia Ibarra, Pátzcuaro, Michoacán, México 61609, phone: 52 (443) 2176668, fax: 52 (434) 3421184, e-mail: (ERSH) edgar_sh50@hotmail.com, (XMG) xmguridi@yahoo.com, (ODD) goodeido@yahoo.com.mx, (GRC) gruiz@uabc.edu.mx, (AFGA) aacosta@ipn.mx.
} 
Student's $t$-test was performed to establish when the calculated $b$ values were close to (isometric growth) or different from 3.0 (allometric growth). The $L-L$ relation was calculated by the simple linear regression:

$$
\mathrm{TL}=b \mathrm{SL}+a
$$

using pooled data over the study period.

A total of 2228 fish specimens, representing 10 families and 14 species were included: Lile nigrofasciata Castro-Aguirre, Ruiz-Campos et Balart, 2002; Pliosteostoma lutipinnis (Jordan et Gilbert, 1882); Agonostomus monticola (Bancroft, 1834); Mugil curema Valenciennes, 1836; Poecilia butleri Jordan, 1889; Centropomus nigrescens Günther, 1864; Lutjanus novemfasciatus Gill, 1862; Eucinostomus currani Zahuranec, 1980; Dormitator latifrons (Richardson, 1844); Eleotris picta Kner, 1863; Gobiomorus maculatus (Günther, 1859); Awaous banana (Valenciennes, 1837); Gobionellus microdon (Gilbert, 1892); Trinectes fonsecensis (Günther, 1862). Results of LWR relations are summarized in Table 1, including number of specimens $(n)$, size range, and $b$ values. Estimations revealed that length-weight for all species were highly correlated, with the coefficient of determination $\left(r^{2}\right)$ ranging from 0.94 to $0.99(P<0.001)$. The $b$ values ranged from 2.912 in Centropomus nigrescens to 3.432 in Poecilia butleri. For all species, $b$ parameter values fall within the expected range of 2.5 to 3.5 (Froese 2006). $L-L$ relations were also highly correlated for all species $(L-$ $L ; r^{2}>0.99, P<0.001$ ) (Table 2). Values for the regression coefficient $(b)$ varied between 1.146 and 1.577 (allometric). Values of $a$ constant (intercept) varied between -0.494 and 0.426 . Allometric growth was recorded for nine species.

The most represented family in our study was Eleotridae (three species). It was followed by Mugilidae and Gobiidae (two species each) while the remaining seven families were represented by a single species only (Table 2 ).
Results were compared with those reported in other studies taken place in the Mexican Pacific coast (González-Acosta et al. 2004, Rojas-Herrera et al. 2009, Velázquez-Velázquez et al. 2009). Four of 14 LWRs (Lile nigrofasciata, Mugil curema, Lutjanus novemfasciatus, and Eucinostomus currani) and one of $L-L$ relations ( $E$. currani) were not within the expected range. The differences in the expected ranges when compared with the estimates provided by other studies may be due to the variation in the sample sizes and the size ranges. The high number of individuals with small length was because estuaries are used as nurseries for fishes such as L. nigrofasciata, Agonostomus monticola, M. curema, and E. currani (see Sandoval-Huerta et al. 2014).

Samples were collected over all seasons therefore $a$ and $b$ parameters should be treated as mean annual values (González-Acosta et al. 2004). The estimated parameters should be applied to species within the specific ranges analysed. To the best of our knowledge, the presently reported study provides LWR parameters determined for the first time for two species (Pliosteostoma lutipinnis, Awaous banana) and $L-L$ relations for six species (L. nigrofasciata, Eleotris picta, Gobiomorus maculatus, A. banana, Gobionellus microdon, Trinectes fonsecensis) (Froese and Pauly 2014).

\section{ACKNOWLEDGEMENTS}

The authors are grateful to everyone who contributed to the field sampling in the project Ictiofauna de la Costa de Michoacán. We grate to Fabiola Ortiz Valderrábano by help in the laboratory work. Funding was obtained from the project CONABIO HJ021 and the Coordination of Scientific Research of the Universidad Michoacana, 2010 projects. AFGA thanks to COFAA and EDI-IPN, and SNI-CONACyT the grants for this research.

Table 1

Length-weight relations (LWR) for 14 fishes of four estuaries from south-eastern coast of Michoacán, central Mexican Pacific

\begin{tabular}{|c|c|c|c|c|c|c|c|c|}
\hline \multirow{2}{*}{ Species } & \multirow{2}{*}{$n$} & \multirow{2}{*}{ Length (SL) $[\mathrm{cm}]$} & \multirow{2}{*}{ Anti-Log $a$} & \multirow{2}{*}{$b$} & \multicolumn{2}{|c|}{$95 \% \mathrm{CI}$ of $\mathrm{b}$} & \multirow{2}{*}{$r^{2}$} & \multirow{2}{*}{ Growth } \\
\hline & & & & & Min. & Max. & & \\
\hline Lile nigrofasciata & 294 & $2.4-7.5$ & 0.00839 & 3.239 & 3.204 & 3.274 & 0.99 & $\mathrm{~A}$ \\
\hline Pliosteostoma lutipinnis & 14 & $7.9-17.5$ & 0.00630 & 3.158 & 2.934 & 3.382 & 0.99 & I \\
\hline Agonostomus monticola & 647 & $2.9-16.4$ & 0.0103 & 3.255 & 3.209 & 3.301 & 0.97 & A \\
\hline Mugil curema $^{\mathrm{J}}$ & 567 & $2.1-16$ & 0.0126 & 3.193 & 3.143 & 3.242 & 0.97 & A \\
\hline Poecilia butleri & 33 & $2.1-5.5$ & 0.0115 & 3.432 & 3.1 & 3.764 & 0.94 & $\mathrm{~A}$ \\
\hline Centropomus nigrescens & 52 & $3.3-30$ & 0.0165 & 2.912 & 2.82 & 3.004 & 0.99 & A \\
\hline Lutjanus novemfasciatus ${ }^{\mathrm{J}}$ & 46 & $2.3-23.7$ & 0.0238 & 3.024 & 2.983 & 3.064 & 0.99 & I \\
\hline Eucinostomus currani ${ }^{\mathrm{J}}$ & 173 & $1.2-8.8$ & 0.0111 & 3.384 & 3.298 & 3.469 & 0.97 & $\mathrm{~A}$ \\
\hline Dormitator latifrons & 187 & $1.4-20.6$ & 0.0148 & 3.309 & 3.242 & 3.377 & 0.98 & A \\
\hline Eleotris picta & 19 & $2.6-22.4$ & 0.0154 & 3.074 & 2.975 & 3.173 & 0.99 & I \\
\hline Gobiomorus maculatus & 96 & $3.9-15.1$ & 0.0135 & 3.042 & 2.969 & 3.114 & 0.99 & I \\
\hline Awaous banana $^{\mathrm{J}}$ & 39 & $2.1-9.3$ & 0.00885 & 3.284 & 3.128 & 3.44 & 0.98 & A \\
\hline Gobionellus microdon & 36 & $1.9-7.9$ & 0.00583 & 3.406 & 3.303 & 3.509 & 0.99 & A \\
\hline Trinectes fonsecensis ${ }^{\mathrm{J}}$ & 25 & $1.7-5.2$ & 0.0242 & 3.158 & 2.92 & 3.397 & 0.97 & $\mathrm{I}$ \\
\hline
\end{tabular}

Parameters of LWR using logarithmic regression (base 10); SL = standard length, $n=$ sample size, $a=$ intercept, $b=$ slope, $r^{2}=$ coefficient of determination, $\mathrm{CI}$ = confidence interval; $\mathrm{I}$ = isometric, $\mathrm{A}=$ allometric; Species names in bold indicate length-weight relations published for the first time; ${ }^{\mathrm{J}}$ indicates juvenile individuals. 
Table 2

Length-length relations (standard length to total length) for 14 fishes of four estuaries from south-eastern coast of Michoacán, central Mexican Pacific

\begin{tabular}{|c|c|c|c|c|}
\hline \multirow{2}{*}{ Family } & \multirow{2}{*}{ Species } & \multicolumn{3}{|c|}{$L-L$ regression parameters } \\
\hline & & $a$ & $b$ & $r^{2}$ \\
\hline Clupeidae & Lile nigrofasciata & 0.0119 & 1.229 & 0.99 \\
\hline Pristigasteridae & Pliosteostoma lutipinnis & -0.194 & 1.206 & 0.99 \\
\hline \multirow[t]{2}{*}{ Mugilidae } & Agonostomus monticola & 0.1278 & 1.162 & 0.99 \\
\hline & Mugil curema ${ }^{\mathrm{J}}$ & -0.0423 & 1.231 & 0.99 \\
\hline Poecilidae & Poecilia butleri & -0.0546 & 1.239 & 0.99 \\
\hline Centropomidae & Centropomus nigrescens & 0.426 & 1.204 & 0.99 \\
\hline Lutjanidae & Lutjanus novemfasciatus $^{\mathrm{J}}$ & 0.0042 & 1.192 & 0.99 \\
\hline Gerreidae & Eucinostomus currani $^{\mathrm{J}}$ & 0.112 & 1.227 & 0.99 \\
\hline \multirow[t]{3}{*}{ Eleotridae } & Dormitator latifrons & -0.0126 & 1.261 & 0.99 \\
\hline & Eleotris picta & -0.0914 & 1.223 & 0.99 \\
\hline & Gobiomorus maculatus & 0.423 & 1.147 & 0.99 \\
\hline \multirow[t]{2}{*}{ Gobiidae } & Awaous banana $^{\mathrm{J}}$ & 0.0382 & 1.175 & 0.99 \\
\hline & Gobionellus microdon & -0.494 & 1.146 & 0.99 \\
\hline Achiridae & Trinectes fonsecensis ${ }^{\mathrm{J}}$ & 0.109 & 1.577 & 0.99 \\
\hline
\end{tabular}

$L-L=$ length-length relation; $a=$ intercept, $b=$ slope, $r^{2}=$ coefficient of determination; Species names in bold indicate length-length relations published for the first time, ${ }^{\mathrm{J}}$ indicates juvenile individuals.

\section{REFERENCES}

Froese R. 2006. Cube law, condition factor and weightlength relationships: History, meta-analysis and recommendations. Journal of Applied Ichthyology 22 (4): 241-253. DOI: $10.1111 / \mathrm{j} .1439-0426.2006 .00805 . \mathrm{x}$

Froese R., Pauly D. (eds.) 2014. FishBase. [version 08/2014] http://www.fishbase.org

González Acosta A.F., De La Cruz Agüero G., De La Cruz Agüero J. 2004. Length-weight relationships of fish species caught in a mangrove swamp in the Gulf of California (Mexico). Journal of Applied Ichthyology 20 (2): 154-155.

DOI: 10.1046/j.1439-0426.2003.00518.x

Quist M.C., Pegg M.A., DeVries D.R. 2012. Age and growth. Pp. 677-731. In: Alexander A.V., Parrish D. L., Sutton T.M. (eds.) Fisheries techniques. American Fisheries Society, Bethesda, MD, USA.
Rojas-Herrera A.A., Violante-González J., Palacios-Salgado D.S. 2009. Length-weight relationships and seasonality in reproduction of six commercially utilized fish species in the coastal lagoon of Tres Palos (Mexico). Journal of Applied Ichthyology 25 (2): 234-235. DOI: $10.1111 /$ j.1439-0426.2009.01219.x

Sandoval-Huerta E.R., Madrigal-Guridi X., Escalera-Vázquez L.H., Medina-Nava M., Domínguez-Domínguez O. 2014. Estructura de la comunidad de peces en cuatro estuarios del Pacífico mexicano central. Revista Mexicana de Biodiversidad 85 (4): 1184-1196.

DOI: $10.7550 / \mathrm{rmb} .42105$

Velázquez-Velázquez E., Navarro Alberto J., Domínguez Cisneros S.E., Vega Cendejas M.E. 2009. Length-weight relationships for 24 fish species in a coastal lagoon of the Mexican South Pacific. Journal of Applied Ichthyology 25 (2): 228-229. DOI: $10.1111 /$ j.1439-0426.2008.01199.x

Received: 15 November 2014 Accepted: 1 March 2015 Published electronically: 30 June 2015 